\title{
Navigating the Contradictions: An ESL Teacher's Professional Self-Development in Collaborative Activity
}

\section{Amanda Giles}

The study contributes to language teacher education research by emphasizing an English as a second language (ESL) teacher's learning through critical activity, which includes my attempts to change my pedagogical practices to provide more equitable educational opportunities for ESL students in the mainstream content classroom. Framed by Engeström's (2001) Cultural Historical Activity Theory (CHAT), the study's purpose was to examine my own professional self-development as an ESL teacher in learning how to initiate and sustain collaboration with a seventh-grade social studies teacher at a suburban middle school in the southeastern United States. Data collection included self-study methods, specifically interviews, collaborative planning sessions, reflective journals, field notes, and e-mail exchanges with a critical friend. The findings showed how I learned to navigate the misuse of planning time and the misrepresentation of collaborative teaching notions as the two major contradictions in collaboration to plan for and teach ESL students. By resolving the contradictions, I negotiated a division of labour and enacted my agency to assume the position of a content social studies teacher, which ultimately sustained the collaborative activity. These findings attend to the complex factors that influence an ESL teacher's professional self-development and agency in collaboration with a social studies teacher.

L'étude contribue aux recherches sur la formation des enseignantes et enseignants de langues en rehaussant l'apprentissage d'une enseignante d'anglais langue seconde (ESL) grâce à l'ajout d'une activité critique tenant compte des tentatives que j'ai faites pour modifier mes pratiques pédagogiques afin de fournir des opportunités éducatives plus équitables aux élèves d'anglais langue seconde au niveau de l'enseignement général. Encadrée par la théorie historico-culturelle de l'activité (CHAT) (2001) d'Engeström, l'étude avait pour objet l'examen de mon propre développement professionnel comme enseignante d'anglais langue seconde alors que j'entreprenais et maintenais une collaboration avec un professeur d'études sociales qui enseignait à des élèves de septième année dans une école moyenne de banlieue du sud-est des États-Unis. Les données de l'étude consistaient en des méthodes d'auto-évaluation, plus précisément des entrevues, des séances de planification concertée, des journaux de bord, des notes de terrain, et des échanges de courriels avec un ami critique. Les conclusions montrent comment j'ai appris à contourner le mauvais usage du temps de préparation et la représentation erronée des notions d'enseignement collaboratif, c'est-à-dire les deux principales contra- 
dictions présentes dans une collaboration visant à planifier et dispenser l'enseignement aux élèves d'anglais langue seconde. En résolvant les contradictions, j'ai négocié une répartition des tâches et adapté mon agentivité de manière à assumer le poste d'enseignante d'études sociales, ce qui a ultimement soutenu l'activité de collaboration. Ces conclusions traitent des facteurs complexes qui influent sur l'auto-développement professionnel et l'agentivité d'une enseignante d'anglais langue seconde en collaboration avec un professeur d'études sociales.

KEYWORDS: professional self-development, ESL and content teachers' collaboration, self-study methods, teacher agency

Recent attention in language teacher education has shifted to focus on the social processes that influence teachers' learning as they participate in the practices of language teaching (Freeman \& Johnson, 1998; Johnson \& Golombek, 2016). Despite increasing research from a sociocultural perspective, what is lesser known is the critical activity of language teachers, specifically in how we confront challenges and engage in professional self-development for English-language teaching and learning. Framed by Engeström's (2001) Cultural Historical Activity Theory (CHAT), the study examined my own professional self-development as an English as a second language (ESL) teacher in learning how to initiate and sustain collaboration with a seventh-grade social studies teacher at a suburban middle school in the southeastern United States.

Given this purpose, the following research questions guided my investigation:

Research Question 1: How did I experience contradictions in collaborative activity to plan and teach collaboratively with a seventh-grade social studies teacher at a suburban middle school in the southeastern United States?

Research Question 2: How did the contradictions contribute to my own professional self-development in learning how to initiate and sustain the collaborative activity?

\section{Professional Development in the United States}

Professional development (PD) in the United States is synonymous with the ways that practicing teachers learn about and improve their pedagogy to influence student outcomes. More traditional approaches of PD resemble what Kumaravadivelu (2003) refers to as the "sage on the stage" where an expert often lectures teachers on ways to improve their pedagogical practices (p. 7). Traditional PD can often be manufactured in response to educational 
policies that reflect neoliberal values and emphasize student achievement, which consequently position teachers as scapegoats when students do not show adequate growth on standardized tests (Smith, 2017).

In language teacher education, Freeman and Johnson (1998) believe cognitive perspectives undergird these traditional learning notions. Cognitive perspectives concentrate on the "internal psychological process isolated in the mind of the learner as an individual, and [are] largely free from the social and physical contexts within which it occurs" (Johnson \& Freeman, 2001, p. 54). Because cognitive learning theorists emphasize the individual's mental processes, they argue that increased knowledge (e.g., through readings, books, or lectures) about the practice of teaching leads to the individual's learning to teach. Traditional PD is criticized because the information rarely makes its way into classrooms to transform teachers' pedagogical practices (Bair, 2014) and often leaves teachers feeling discouraged (Smith, 2017). In a sociocultural learning framework, scholars argue that the learner's social processes precede his or her learning opportunities (Vygotsky, 1978), which consequently means that "one must look at the social activities that the individual engages to see how they reappear as mental activities in the individual" (Johnson, 2006, p. 237). This view conceptualizes learning as a complex, social process where language teachers begin to rethink their identity, beliefs about students, and the actual teaching activity (Johnson \& Golombek, 2016). Through participation in social activities, language teachers make visible and renew their understandings; this dynamic process ultimately transforms the teaching activity and leads to learning.

\section{Teachers' Professional Agency}

Given the above-mentioned sociocultural learning notions for teachers' PD, a teacher's professional agency can work to influence the teachers' learning opportunities. This study's view of agency aligns with more sociocultural (Ahearn, 2001; Duff, 2012) and ecological (Biesta \& Tedder, 2007) perspectives. As Duff (2012) states, "Agency refers to people's ability to make choices, take control, self-regulate, and thereby pursue their goals as individuals leading, potentially, to personal or social transformation" (p. 417). Nonetheless, Ahearn (2001) reminds us that the individual's actions are always "socioculturally mediated," which acknowledges how social and cultural discourses in society enhance and/or constrain the individual's "capacity to act" (p. 112). These agentic actions are also always located within past, present, and future time configurations (Biesta \& Tedder, 2007, p. 135).

Early work on teachers' professional agency have examined how teachers' beliefs (Biesta, Priestley, \& Robinson, 2015) and identities (Buchanan, 2015; Kayi-Aydar, 2015) shape their agency. A strand of research also explored how the sociocultural influences the teachers' actions (Buchanan, 2015; Kayi-Aydar, 2015; Priestley, Edwards, Priestley, \& Miller, 2012). More 
specifically, this research included how curricular reform (Priestley et al., 2012) and accountability pressures (Buchanan, 2015) enhanced and constrained teachers' agency.

Considering these earlier studies, researchers still need to explore further teachers' professional agency (Biesta \& Tedder, 2007; Priestley et al., 2012). When researchers explore this topic, they tend to focus on the macro influences of teachers' agency; yet, agency in relation to "the activities of teachers in schools" (Priestley et al., 2012, p. 193) is lesser known. Accordingly, this study answers the call to examine the ESL teacher's actions in learning how to collaborate with a social studies teacher.

\section{Content and ESL Teachers' PD as Collaborative Activity}

Effective PD requires teachers' collaboration because it encourages teachers' learning through professional social networks in authentic school settings (Darling-Hammond, Hyler, Gardner, \& Espinoza, 2017). Previous research argued that content and ESL teachers' collaboration generated opportunities for teachers' PD and learning (Giles \& Yazan, forthcoming 2019; Dove \& Honigsfeld, 2018; Martin-Beltrán \& Peercy, 2014; Peercy, Ditter, \& DeStefano, 2016). Content and ESL teachers "co-construct knowledge" (Martin-Beltrán \& Peercy, 2014, p. 1; see also Peercy, Ditter, \& DeStefano, 2016; Peercy, MartinBeltrán, Yazan, \& DeStefano, 2017) through collaborative inquiry (Baecher, Rorimer, \& Smith, 2012), which can lead to teachers' greater awareness of ESL students' language needs (Giles \& Yazan, forthcoming 2019). The current investigation extends and builds on this existing literature to focus on how I pursue my own professional self-development.

Sociocultural researchers use Engeström's (2001) CHAT as a lens to explore the interrelated factors that contribute to the teachers' learning in activity. Engeström's (2001) model includes the following components: subject, tools, division of labour, object, rules, community, and outcome. The subjects emerge as the activity's focal participants because the activity unfolds from their perspective. The subjects use culturally mediated tools to work toward a specific object, which is the "problem space" that directs the subjects' efforts (Johnson, 2009, p. 83). The tools "mediate social interactions and learning" (Jenlink, 2013, p. 221), and help the subjects negotiate a division of labour by differentiating responsibilities within a sociocultural community. The community provides the activity's context, which is governed by rules that influence the subjects' participation. The subjects' involvement leads to a certain outcome, which includes learning. Engeström (2001) extends this model to include multivoiced subjects and contradictions. Multivoiced subjects delineate the possibility for the subjects' diverse interests and expertise. Contradictions are "structural tensions within and between activity" (Engeström, 2001, p. 137) that are necessary and must be resolved for learning and development to take place. 
When applying CHAT to this study, I conceived that the collaborating social studies teacher and I were the subjects in the activity. We used culturally mediated tools and negotiated a division of labour to work toward the activity's object, which was collaboration for ESL students in the social studies classroom. The sociocultural community was a middle school in the southeastern United States, and the rules were state, district, and school regulations for collaboration and ESL instruction. I viewed contradictions as tensions or hindrances as an inherent and necessary part of collaboration because their resolution leads to my own learning.

\section{Self-Study Methodology}

I employed a self-study methodology (Loughran, 2004; Samaras, 2011) to explore the contradictions I experienced in collaborating with a seventh-grade social studies teacher in the content classroom. A self-study methodology is self-initiated and aims to "[impact] learning" and "improve professional development" (Samaras, 2011, p. 81). Self-study methodologists encourage the use of a critical friend to help the researcher clarify, critique, and refine ideas (Loughran, 2004; Samaras, 2011). Following this advice, I exchanged several e-mails with a critical friend who was a mentor and colleague; these conversations helped to sharpen my understandings and ultimately validated this study's quality.

\section{The School and Classroom Context}

Located in the southeastern United States, Starcreek Middle School (pseudonym) had 807 students during the 2016-2017 school year. There were 26 students classified as ESL students, which meant that these students identified an additional language on a home language survey at registration and made a qualifying score (4.7 or below) on the World-class Instructional Design and Assessment (WIDA)-Access Placement Test (W-APT). The W-APT's purpose was to assess whether students with an additional language in their background needed language services taught by the ESL teacher in the ESL program. All students were placed in four content classes (e.g., social studies, language arts, math, and science) at the time of registration regardless of their score on the W-APT. Qualifying students also were enrolled in a 55-min ESL class period where they received language instruction taught by me; hence, the majority of language instruction took place in content classrooms with English-only instruction.

\section{The Collaborating Teacher}

Morgan (pseudonym) was the seventh-grade collaborating social studies teacher in the collaborative activity. Morgan had a total of 9 years of teaching experience during the time of this study and was beginning his third year 
at Starcreek. He graduated with a bachelor's degree in secondary education with social studies as his primary concentration and had a master's degree in administration. Even though Morgan reported working with diverse students whom he described as low readers, he did not have collegiate training nor previous experience planning for and teaching ESL students in the social studies classroom. During the 2016-2017 school year, Morgan taught five ESL students who were spread across two social studies classes. In the collaborative teaching class, there was one ESL student who identified Spanish as his home language. Collaboration emerged during the second semester because Morgan frequently expressed difficulty working with this particular student. When I asked Morgan to describe how I could help, he explained,

I've not been able to figure [the student's name] out. He's done consistently bad on every test. I've tried reviewing with him and studying with him trying to make sure, giving him a study guide, the key without the ESL teacher's, without your help. [Now] I am sending him to you to maybe read the test or go over it with him. Get that one-on-one with him. (Interview \#1, February 23, 2017)

By continuing to send the ESL student to my classroom, Morgan was not taking or sharing responsibility for the student's content or language objectives and continued to view our ESL student through a deficit perspective. Morgan believed he had expended his efforts trying to help the ESL student. His words (e.g., "I'm sending him to you") indicated that he did not know how to help the student, because by "sending him to [me]," he was expecting me to teach social studies content and language solely to the ESL student. Morgan's training and experience was common among mainstream content teachers (Wang, Many, \& Krumenaker, 2008); however, his action was not a sustainable solution for the ESL student's content and language instruction.

\section{My Journey to Become an ESL Teacher}

I began teaching eighth-grade language arts at Starcreek in 2010. I taught many ESL students in my language arts classes as I majored in Spanish and English in college. Shortly into my career, I began conversations with my administrator about becoming the ESL teacher but would not assume this position primarily until I could secure full-time employment. During my tenure as a language arts teacher, I taught a pull-out ESL class period, which meant that I delivered language instruction specifically designed for ESL students in a separate location from the mainstream classroom. I also co-taught with the current ESL teacher in the ESL classroom.

It is important to note that the current study's state requirements allow for a person who holds teaching certification in an additional language and/ or language arts to assume the position of ESL teacher. I met both requirements because I also hold certification in Spanish and language arts. When I accepted the ESL teacher position in 2010, I wanted to advocate for the 
ESL students' academic, emotional, and social needs and work to promote equitable learning opportunities for them. My belief about ESL instruction necessitates ESL and content teachers' shared responsibility. Moreover, I conceive collaboration as a way to promote this shared responsibility. Hence, this study explored my own challenges in engaging in collaborative activity to plan for and teach ESL students with Morgan in the content classroom and scrutinized how these contradictions contribute to my own professional self-development.

\section{The Collaborative Process}

Morgan and I collaborated to plan and teach two lessons based on the state's course of study in social studies standards during the second semester, which lasted 5 months in duration. I video-recorded one planning session where Morgan and I discussed and developed a lesson plan based on a previous lesson that Morgan had created. I paid attention to how our actions in collaboration created (or constrained) possibilities because these actions would ultimately influence how I learned to initiate and sustain the collaborative activity. I wrote field notes to record these observations. Upon completing the first planning session, Morgan and I co-taught the lesson together, and after the collaborative teaching session, Morgan and I wrote a reflective journal that described our collaborative teaching roles and challenges that we experienced in planning for and teaching our ESL student. We completed this process a second time, during which I continued to reflect on Morgan's and my roles in collaboration as well as my renewed understandings on how to initiate and sustain collaboration. I continued to write field notes and exchange e-mails with my critical friend to document my own professional self-development.

\section{Data Collection Methods}

Data collection methods included the following sources:

- Three semistructured interviews,

- Two video-recorded collaborative planning sessions,

- Two reflective journals written by Morgan,

- Two reflective journals written by me,

- Seven field notes, and

- Thirteen exchanges with a critical friend. 
All data collection methods occurred within a 5-month duration and included the following:

- The three audio-recorded interviews lasted approximately $25 \mathrm{~min}$ in duration. The interview questions (e.g., What should the ideal roles and responsibilities of the ESL and content teachers be in working with ESL students?; How has collaboration changed the way you design lessons for ESL students?) asked about Morgan's previous experiences working with ESL students and learning in collaboration.

- The two video-recorded collaborative planning sessions sought to explain the collaborative activity. The first planning session lasted approximately $14 \mathrm{~min}$, and the second session lasted about $38 \mathrm{~min}$.

- Also semistructured were the reflective journals, in which I asked Morgan to respond to six to seven questions (e.g., What did you learn in working together toward teaching ESL students? What were the benefits and challenges of collaborative planning and teaching?). As the ESL teacher, I also wrote reflective journals with the same six to seven questions.

- Field note entries occurred after each interview, planning session, and teaching session. In these entries, I focused specifically on my learning processes related to initiating and sustaining collaborative activity with Morgan.

- The e-mail exchanges with my critical friend served to help me discuss the challenges and explain my own learning processes in collaborative activity.

\section{Data Analysis}

To begin analysis, I transcribed the interviews and collaborative planning sessions and kept them on my password-protected computer. When I began coding the data, I looked closely for the contradictions that I experienced in collaborative activity with a social studies teacher. I also examined the data sources for evidence of how I navigated these contradictions. To this aim, I employed Saldaña's (2013) techniques for descriptive and in vivo codes during the first coding cycle. Descriptive codes are nouns that reflect the conversational gist in the data selection, and in vivo codes generate exact words from the data in an effort to emphasize the participants' actual speech (Saldaña, 2013). This analysis produced 26 codes that evinced the activity's contradictions and my own efforts to navigate the contradictions in collaborative activity. 
During the second coding cycle, I initially relied on Engeström's (2001) CHAT components (e.g., subject-ESL teacher, subject-content teacher, division of labour, and tools) as analytic tools to place the initial codes into four categories. By placing the initial codes into these categories, I was able to concentrate on the contradictions that I experienced (e.g., Subject-ESL teacher) in the collaborative activity and narrow the codes that occurred across three or more sources to triangulate the data. While this analysis helped me understand the collaborative activity from my perspective, it did not completely explain how my navigation of contradictions led to my own learning. Thus, I returned to my initial codes and fit them together to form emerging patterns/ themes given the research questions (see Table 1). This deductive coding analysis allowed me to identify two major contradictions (i.e., misuse of planning time and misrepresentation of collaborative teaching notions) and understand how I worked to resolve them (i.e., volunteering to create parts of the lesson).

In "theme-ing the data" (Saldaña, 2013, p. 175), I reflected on how the emerging themes/patterns fit together to form theme statements. At this stage, I asked myself questions (e.g., What am I learning? and How am I learning it?), which made it possible to evince how I learned to navigate the contradictions in collaboration, which is my own professional self-development.

Table 1

Emerging Themes and Initial Codes with Number of Coding Counts

\begin{tabular}{|c|c|c|c|}
\hline \multicolumn{2}{|l|}{ Theme 1} & \multicolumn{2}{|l|}{ Theme 2} \\
\hline \multicolumn{2}{|c|}{$\begin{array}{c}\text { Content teacher's inexperience in working with } \\
\text { ESL students }\end{array}$} & \multicolumn{2}{|c|}{ Misuse of planning time } \\
\hline Initial code & $\begin{array}{l}\text { Number of } \\
\text { coding counts }\end{array}$ & Initial code & $\begin{array}{l}\text { Number of } \\
\text { coding counts }\end{array}$ \\
\hline $\begin{array}{l}\text { Doesn't remember the ESL } \\
\text { teacher's name }\end{array}$ & 2 & $\begin{array}{l}\text { ESL teacher's multiple } \\
\text { responsibilities }\end{array}$ & 7 \\
\hline ESL students are struggling & 5 & Wrestling with my schedule & 6 \\
\hline $\begin{array}{l}\text { ESL students have no unique } \\
\text { differences }\end{array}$ & 3 & Needing more time to collaborate & 13 \\
\hline $\begin{array}{l}\text { Forgetting to accommodate for } \\
\text { ESL students }\end{array}$ & 2 & $\begin{array}{l}\text { Off task during the collaborative } \\
\text { planning session }\end{array}$ & 3 \\
\hline Letting resource accommodate & 1 & & \\
\hline Language is a problem & 2 & & \\
\hline $\begin{array}{l}\text { Lumping ESL students with } \\
\text { struggling readers }\end{array}$ & 5 & & \\
\hline $\begin{array}{l}\text { Content teacher's inexperience } \\
\text { with stations }\end{array}$ & 2 & & \\
\hline No coursework related to ESL & 1 & & \\
\hline
\end{tabular}




\begin{tabular}{|c|c|c|c|}
\hline \multicolumn{2}{|c|}{$\begin{array}{l}\text { Content teacher's inexperience in working with } \\
\text { ESL students }\end{array}$} & \multicolumn{2}{|c|}{ Misuse of planning time } \\
\hline Initial code & $\begin{array}{l}\text { Number of } \\
\text { coding counts }\end{array}$ & Initial code & $\begin{array}{l}\text { Number of } \\
\text { coding counts }\end{array}$ \\
\hline $\begin{array}{l}\text { No experience working with ESL } \\
\text { teacher }\end{array}$ & 1 & & \\
\hline $\begin{array}{l}\text { Unequipped to teach ESL } \\
\text { students }\end{array}$ & 2 & & \\
\hline $\begin{array}{l}\text { Challenging to accommodate for } \\
\text { ESL students }\end{array}$ & 2 & & \\
\hline Theme 3 & & Theme & \\
\hline Misrepresentation of collaborativ & teaching notions & $\begin{array}{r}\text { The ESL teacher volunte } \\
\text { of the les }\end{array}$ & 0 create parts \\
\hline Initial code & $\begin{array}{l}\text { Number of } \\
\text { coding counts }\end{array}$ & Initial Code & $\begin{array}{l}\text { Number of } \\
\text { coding counts }\end{array}$ \\
\hline $\begin{array}{l}\text { Content teacher's unequal } \\
\text { division of labour }\end{array}$ & 3 & $\begin{array}{l}\text { Offering to create parts of the } \\
\text { lesson }\end{array}$ & 10 \\
\hline $\begin{array}{l}\text { ESL teacher's unequal division } \\
\text { of labour }\end{array}$ & 5 & Creating the lesson activity & 7 \\
\hline Unequal sharing of responsibility & 6 & Taking a lead role & 8 \\
\hline $\begin{array}{l}\text { Collaborative involves planning } \\
\text { and teaching }\end{array}$ & 4 & & \\
\hline $\begin{array}{l}\text { Didn't reflect our ideal } \\
\text { collaboration }\end{array}$ & 3 & & \\
\hline $\begin{array}{l}\text { Helping the ESL student/didn't } \\
\text { teach }\end{array}$ & 13 & & \\
\hline Unequal sharing of resources & 2 & & \\
\hline
\end{tabular}

Note. ESL = English as a second language.

\section{Issues of Trustworthiness}

I attended to issues of trustworthiness to strengthen the study's quality. To ensure transparency throughout the research process, I provided the codes during the first and second coding cycle to make known how I approached and synthesized these data. In this way, I stated all emerging themes, initial codes, and the number of counts per each code. I also included a positionality statement earlier to make my biases and assumptions known (Merriam \& Tisdell, 2016) and discussed my methodological procedures in detail with the critical friend to maintain transparency. 


\section{Findings}

I will discuss how I experienced the two contradictions in the collaborative activity: (a) the misuse of collaborative planning time and (b) the misrepresentation of our ideal collaborative teaching scenario; I will then explain how resolving these contradictions showed (c) my own professional self-development as a language teacher interested in initiating and sustaining collaboration at Starcreek Middle School.

\section{Contradiction \#1: Misuse of Collaborative Planning Time}

The first contradiction that I experienced during the first collaborative cycle was Morgan's and my misuse of planning time. Our planning time lasted about 14 min, with the majority of the time focused on Morgan's use of reading passages in the social studies classroom, which was not aligned with the lesson's purpose. I began the first planning session by asking Morgan to clarify the lesson objectives:

Me: So, what are you thinking about doing?

Morgan: Well, I'm having to change some things because last year [a language arts teacher's name] did a cross-teaming activity with the book they were reading, which was about Korea. But, they are not even going to be reading it until after spring break, so I've got to either scrap that or either just move it to next week.

Me: This is When My Name was Keiko, right?

Morgan: Yeah. Since they haven't even started that, it wouldn't do us any good to start that, but I've got China next week, and it'll probably take Monday and Tuesday. Monday will be like a preview and vocabulary, and we'll get started on this PowerPoint. They put a picture and then they get a definition, and then as we go, they have questions to answer on their PowerPoint. Then, with their group they have to identify cost and benefits of the one child policy.

Me: So, do you want me to help with that?

Morgan: We can. It's what I've got, so we can do that. (Collaborative Planning Session \#1, March 10, 2017)

Morgan's response suggests that he wanted to explain a PowerPoint related to China's population growth and the one child policy law during the first collaborative teaching session; however, what is missing in this dialogue is the actual contents of the PowerPoint presentation, which were never discussed in the planning session. After this exchange, Morgan agreed to share 
the presentation with me so that I could make suggestions to help our ESL student. We also established the teaching date, but we did not schedule a second planning session to discuss my suggestions. To complicate matters further, Morgan sent me an e-mail following this planning session to reschedule the teaching date because he was going to be absent on this date. Because Morgan and I did not meet a second time, we were not able to establish clear learning expectations for students nor discuss teaching roles. Lacking sufficient planning time coupled with unclear expectations made the activity's object (e.g., collaboration for ESL students in the social studies classroom) harder to accomplish and created an outcome not congruent with my original intention of promoting a shared responsibility among all teachers.

To this end, this misuse of planning time led to an outcome that perpetuated an unequal division of labour for Morgan. In the first interview, Morgan explained the contradictions he experienced in previous collaborative teaching partnerships, stating,

The only thing that's tough about setting up those situations is I might teach three classes by myself and have one co-teaching [class] because [the co-teachers] are going to have other responsibilities throughout the day and that kind of thing. (Interview \#1, February 23, 2017)

Morgan felt like he must assume the brunt of responsibility because the co-teacher was not available outside of the collaborative teaching class to share instructional duties. While Morgan understood the co-teacher had other responsibilities, he had to teach three classes without the co-teacher; hence, this created an unequal division of labour for the content teacher because he had to envision the same lesson in multiple ways, specifically one with and without the co-teacher.

Morgan and my collaborative teaching session during the first collaborative cycle did very little to debunk Morgan's ideas based on his previous experiences because I was only available during the class period with the ESL student. When asked to express what he would change during the collaborative teaching session, Morgan explained,

The only thing I would change would be more time. I wish we were able to collaborate on a regular basis, but you are the only ESL teacher for three grades. Being spread too thin doesn't come close to describing your responsibilities. (Reflective Journal \#1, April 24, 2017)

Morgan's statement indicates how we needed more planning time "to collaborate on a regular basis," yet his justification pinpoints my duties within the school community as the primary reason we did not have more planning time. Here, in this next excerpt, Morgan attributed limited collaboration to my own caseload because I served three grade levels of ESL students. I asked 
Morgan to describe further what he meant by "being spread too thin" in a follow-up interview:

Me: Can you talk to me a little bit about what you meant when you said being spread too thin doesn't come close to describing my responsibilities?

Morgan: [Laughs] Yeah, I mean I can't imagine, I mean how many kids are on your caseload?

Me: 26

Morgan: Yeah.

Me: And that doesn't include former ESL students, so kids who have recently exited, so all and all I have 60.

Morgan: Right, and those are spread over one period. How many different classes on how many different hallways, are there?

Me: Yeah, they're on all different hallways. They're across all three grades, all three teams.

Morgan: I mean yeah, that's what I'm saying. Even if you went to one class every day it would take you like three weeks to probably see every kid in their classroom which I mean isn't fair, so I think you having a [ESL] period, is it just at the end of the day or is there another one?

Me: No, I have two [ESL] periods. So, I have a class of sixth graders and then we combined 7th and 8th graders, so that I could have more time to go into content classes.

Morgan: So, having those two [ESL] periods is huge. I know when I was at the other school, I don't think they even had that, but I mean all that does is put that much more pressure on the content teachers because you can't possibly meet all of the needs of the kids during the week and meet with teachers to do stuff. I mean that's what I was thinking about. How in the world can you get to every kid and make sure they're progressing and meeting their goals? (Interview \#2, May 1, 2017)

This exchange helped describe my responsibilities, which were distinct from the content teacher who typically assumed responsibility for one content area and grade. My duties mentioned here included servicing all 26 ESL 
students including recently exited students, teaching two ESL class periods, and supporting all content teachers. Beyond these duties, I was frequently asked to translate for Spanish-speaking parents and students as well as teach a Spanish I course during this school year. In this dialogue, while Morgan noticed that I had various responsibilities, he only understood my duties to the extent that they impacted (and constrained) what was going on in the content classrooms (e.g., "help teachers to do stuff"). His words, "put that much pressure on the content teachers," indicates that he felt added pressure because he could not imagine how I could possibly meet every need of all ESL students across three grades. My inability to meet the ESL students' needs from his perception only served to magnify his own workload. He only viewed my responsibilities valuable if they were relevant to the content teacher. If not applicable to his content, then he felt he still assumed more responsibility by my own inadequacies based on his perceptions. Thus, our lack and misuse of planning time was a contradiction that made visible the unequal division of labour within the collaborative activity.

\section{Contradiction \#2: Misrepresentation of Our Ideal Collaborative Teaching Scenario}

Another contradiction that I experienced in the collaborative activity was that Morgan and my collaborative teaching scenario during the first collaborative cycle did not reflect our ideal definitions. In the first interview, Morgan and I discussed his definition of collaborative teaching:

Me: Tell me what your definition of co-teaching would be. If you were to co-teach with the ESL teacher?

Morgan: Co-teach?

Me: Yeah, what would that look like?

Morgan: Like two weeks ago with the technology coach. We did a lesson on the Nile River with some Google and technology. But you know we would work together on a lesson plan to see where my strengths would be, where your strengths would be, and try to divide up who's talking. So, it wouldn't be me talking the whole time, and you standing over the other kids. It would be maybe I'd give the first part of the instruction and we'd do whatever. And all right you're up, so that way you are able to hover and check on who needs help, and then while you are leading instruction, I'll do the same thing.

Me: So, you would be okay with that? 
Morgan: Yeah, that's what co-teaching is. To me having somebody in there to help when we are doing assignments, or you know working on something, and the kids need help. That would be a time for you to help, and it'd be helpful, but if we're co-teaching, it needs to be we're both teaching. I've got a part. You've got a part. That's the whole co-part. The other one to me is like you're an aide in the classroom, if we're doing it that way where you're just hovering. (Interview \#1, February 23, 2017)

Morgan's definition of collaborative teaching is similar to my own definition because collaborative teaching involves both teachers planning and instructing the lesson. Morgan juxtaposed this definition to "an aide in the classroom" who only supported the students without sharing in planning and instruction. He also viewed collaborative teaching as a way to highlight the collaborating teachers' strengths so that all students understood the content and language objectives; this implies an equal division of labour where collaborating teachers work together to strengthen instruction. Morgan also stated that he would be comfortable engaging in this collaborative activity with me because it aligned with his beliefs about collaborative teaching. He also recognized that failing to enact this definition in practice relegated the ESL teacher's position to a more supporting role (e.g., "an aide in the classroom"). While Morgan believed this assistance might "be helpful," he did not believe that it paralleled his ideal definition.

During the first collaborative teaching session, however, my role resembled an assistant's role, which contradicted both subjects' beliefs about collaborative teaching. When asked about the collaborative teaching session, Morgan recognized that our roles contradicted his ideal notions:

Me: To what extent do you feel like our co-teaching experience reflected your ideal co-teaching experience?

Morgan: I mean-

Me: It's okay if you say it didn't.

Morgan: I mean it didn't because we didn't have enough time to plan, and with both of our schedules, we just didn't have enough time to plan it out. You were in there to help and supplement, but you know we didn't have time to go over the whole lesson and say, "Hey, you're going to do this part, and I'm going to do that part." But I think if we had had time to do that, it would have been good. (Interview \#2, May 1, 2017)

Lack of planning time and discussion of instructional roles attributed to the misrepresentation of our ideal collaborative teaching scenario. Because the 
first collaborative teaching cycle contradicted the subjects' notions, it contributed to the activity's initial outcome that illuminated the unequal division of labour and my relegated role.

\section{Learning to Sustain Collaboration: My Professional Self- Development}

Examining how contradictions are resolved is crucial because it opens up possibilities for transformation (e.g., my learning) within the activity. Therefore, to resolve the above-mentioned contradictions, I had to learn how to use planning time more effectively and align the second collaborative teaching session to our ideal notions to sustain the collaborative activity. To this end, I reflected on the first collaborative cycle and decided that I would take an active part in the second collaborative cycle:

The most important thing that I would change is my involvement in the collaborative planning and teaching sessions. I may not be able to change the amount of time that Morgan and I have to plan, aside from protecting this time. I also can't change his perception of my crazy schedule. I also can't "make him" be more available to plan. However, I can volunteer to create activities during the planning sessions and actually help Morgan teach them. Will this make a difference? I'm not sure, but it is worth a shot. It might mean that I do more of the work, but I have to do something. Otherwise, this experience will be no different than his previous "co-teaching" experiences. (Field notes, May 2, 2017)

I resolved to help Morgan create activities during the second collaborative cycle, even though I was not convinced that it would "make a difference" to change the activity's ultimate outcome. I was not specific on how I would offer to help. Also, I resolved to "[protect] the [planning] time," which implied that I would make myself available to plan as needed and use the time to concentrate on the learning objectives. I did not try to change "his perception of my crazy schedule"; instead, I wanted to try to use the planning time more effectively, hoping that my own effort would bring about our ideal collaborative teaching notions in practice.

There was a noticeable difference in my effort during the planning session in the second collaborative cycle. Morgan told me that he wanted to deliver information about three religions (e.g., Islam, Christianity, and Judaism), Syria, and background information on the Israeli-Palestinian conflict. I suggested station activities as a suitable way to deliver the lesson content as Morgan wanted to preview all information in one class period. Morgan stated that he had not "done stations a whole lot," so I used his stated inexperience as an opportunity to be the leader in the planning session (Collaborative Planning Session $\# 2$, May 10, 2017). Throughout the entire planning session, 
I volunteered to create station activities while including Morgan's content objectives as well as negotiating our division of labour within the collaborative activity:

Me: I'd be glad to help you create some of the stations. Do you want to do the role play one? Since you have a better idea of what you're wanting for the role play? Like adding in and coming up with dialogue?

Morgan: Yeah, sure.

Me: So, then you'll handle that station. I can do, I mean I could do the other two. I mean I need to watch the videos anyway, so I know what I'm actually talking about. (Collaborative Planning Session \#2, May 10, 2017)

Prior to this exchange, Morgan stated that he wanted to create a dialogue between a rabbi, an imam, and a preacher to help students understand the three religions. Apart from this suggestion, Morgan did not specify what he wanted covered in the other two stations; hence, in this exchange, I established how Morgan and I were going to deliver the content (e.g., station activities) to students as well as divided the instructional responsibilities. In doing so, I assumed the position of a social studies content teacher while still honouring Morgan's content contribution. I also negotiated a division of labour where I asked Morgan to create the activity that aligned with his original idea and volunteered to create the other two activities by using the resources that Morgan offered, which included videos about Syria and the Israeli-Palestinian conflict as well as four questions about the conflict.

Toward the end of the collaborative planning session, I clarified my responsibilities to create the two activities to ensure that they aligned with Morgan's lesson objectives:

Me: So, I'll be in charge of stations 1 and 3. We're looking at about 15 minutes for each station.

Morgan: Did you say 1 and 3?

Me: Yeah, I need to look at [the videos], and I'll pull something together later tonight.

Morgan: So, you mean you would make-

Me: the viewing guide and whatever other activity they're going to do. They will be self-directed activities. I'm going to look at [the 
four questions about the Israeli Palestinian conflict]. I'm going to use [these questions] ... right?

Morgan: Yeah, all right.

Me: And then I mean I may adapt [the questions to fit the activity]. I'll come up with instructions, so it's self-directed.

Morgan: Yeah, okay. (Collaborative Planning Session \#2, May 10, 2017)

I continued to assume the position of a social studies content teacher because I set the parameters of the lesson by specifying the time allotted for each station activity. I also insisted that I would use the resources that Morgan offered to create the activities. We shared and co-edited the documents in a Google folder. I created a graphic organizer for the first station activity on the Israeli-Palestinian conflict by using Morgan's suggested videos and questions. I created the second station activity completely from scratch because Morgan did not have resources on Syria. Morgan made no changes to these activities when I shared the activities with him.

During the actual collaborative teaching session, our instructional roles paralleled our contribution during the planning session. I supervised students in the two stations, while Morgan facilitated the role-play activity about the three religions. I intentionally created my activities to be student-directed, so that Morgan could implement these activities easily when I was not available to co-teach in his remaining three content classes. The students initially could not watch the YouTube videos I included because of the district's security filters. To circumnavigate this potential contradiction, I quickly decided to download all YouTube videos and put them in the students' Google Classroom so that they could view them without Internet access. Morgan gave instructions while I performed this task, which took about $5 \mathrm{~min}$. The rest of the class period went smoothly as Morgan and I performed our instructional tasks.

In the final interview, Morgan described further my contribution to the collaborative planning and teaching session during the second collaborative cycle:

Me: In your journal, you said that I was able to help with some problems that came up. Can you explain what you mean by the problems that came up, specifically?

Morgan: Well, yeah, for this lesson some of the videos that we had the kids watch got blocked on YouTube, so I was able to get the kids started on different parts of the assignment, while you got the videos downloaded into Google Classroom so that they could access it. So 
that saved about twenty minutes because kids wouldn't have known what to do while I was trying to get stuff corrected, so it made it run a lot smoother.

Me: You also said that I was helpful in planning and creating the lesson, can you talk about what that entailed?

Morgan: Well, I think some of the stuff, the way the lesson worked and flowed I wouldn't have, I mean it was your ideas. You built some of the components or parts of the lesson, so it took a little bit of time to meet together and plan. But, then creating some of the stuff for the lesson, it was split between the two of us, so I think it saved both of us time. (Interview \#3, May 25, 2017)

This excerpt illustrates how I used my knowledge of technology to help the lesson "run a lot smoother." In addition, it shows how my effort to create two lessons helped balance the division of labour so that Morgan did not feel he had to assume all responsibility for the content. In this dialogue, Morgan believed that the duties were "split between the two of us," which "saved both of us time." He ultimately credited the ease at which the lesson flowed to "[my] ideas" and admitted that he would not have been able to conceptualize the lesson without my assistance. When asked to what extent he was likely to engage in future collaborative efforts with the ESL teacher, Morgan responded, "I am very likely. I loved the experience and would gladly do it again because you helped plan and create the lesson" (Reflective Journal \#2, May 22, 2017).

In reflection, I learned how to resolve contradictions in collaboration, which contributed to my own professional self-development as a language teacher interested in initiating and sustaining collaboration, stating,

In future collaborative planning and teaching sessions with content teachers, I have to volunteer to create part of the lesson, even if it is a small part, to the extent that the content teacher will accept assistance because this contribution made the collaboration work between Morgan and me. (Field notes, May 26, 2017)

My reflection shows that I believed creating parts of the lesson helped sustain collaboration. My words (e.g., "this contribution made the collaboration work") further reiterate my own professional self-development in the collaborative activity in learning how to collaborate with Morgan for ESL students in the content classroom. In this way, resolving contradictions provided an opportunity for me to learn how to strengthen a collaborative teaching partnership with a content teacher at Starcreek. 


\section{Discussion}

These findings made visible the contradictions I experienced within the collaborative activity, namely, the misuse of planning time and the misrepresentation of collaborative teaching notions with our ideal definitions. It also showed how I learned to resolve these contradictions by taking an active role in the collaborative planning and teaching sessions, which contributed to my own professional self-development as a language teacher. In this way, this study contributes to discussions relating to the ESL teacher's learning and agency in collaborative activity.

\section{The ESL Teacher's Learning}

My learning was a mediational process in which I learned how to negotiate a division of labour and co-create the lesson in collaborative activity. In doing so, I assumed the position of a social studies teacher while still using Morgan's content objectives and resources. This finding is consistent with earlier studies that show how content and ESL teachers' collaboration can be a potential space for teachers' learning (Giles \& Yazan, forthcoming 2019; Martin-Beltrán \& Peercy, 2014; Peercy, Ditter, \& DeStefano, 2016; Peercy, Martin-Beltrán, Yazan, \& DeStefano, 2017). This study extends earlier work by illustrating how my involvement in collaborative activity can contribute to my own professional self-development as an ESL teacher. An outgrowth of my professional self-learning also created a strengthened teaching partnership because Morgan expressed his willingness to collaborate with the ESL teacher in future lessons. This strengthened teaching partnership aligns with previous studies that show how content teacher and ESL teachers' collaboration can build interpersonal qualities between teachers (Baecher, Rorimer, \& Smith, 2012).

\section{The ESL Teacher's Agency}

My own agency was crucial in sustaining the collaborative activity (Ahearn, 2001; Duff, 2012). Enacting agency, I made the choice to initiate collaboration with a content teacher when collaboration was historically not the teaching norm within the school community. I also resolved to create lesson activities and even assumed a position typically only associated with the content teacher. This role is distinct from previous studies that report the ESL teacher's relegated role within the school community (Ahmed Hersi, Horan, \& Lewis, 2016; Arkoudis, 2003; Creese, 2002).

Nevertheless, my ability to enact agency was "socioculturally mediated" (Ahearn, 2001, p. 112); thus, my agency is supported by my previous experience as a content teacher and my professional relationships within the school community. These findings extend earlier work to show a language teacher's agency as I make decisions (Duff, 2012) to navigate the activity's contradictions (Priestley et al., 2012). These findings also support earlier research 
that argues that a teacher's agency can only be understood socioculturally (Buchanan, 2015; Kayi-Aydar, 2015).

\section{Limitations}

This study extends previous research on ESL and content teachers' learning in collaboration and teacher agency but delimits its focus to one ESL teacher's experience in learning to navigate the contradictions in collaborative activity at a middle school in the southeastern United States. Another limitation is the study's short duration, which resulted in limited collaborative sessions and exchanges. In addition, quality-ensuring measures, such as peer audit, the establishment of intercoder reliability, and member checks could have been taken to strengthen the trustworthiness of this study (Creswell \& Miller, 2000; Miles, Huberman, \& Saldaña, 2014).

\section{Practical Implications and Future Directions}

I offer practical implications for educational stakeholders who wish to initiate and sustain ESL and content teachers' collaboration. First, someone committed to sustaining collaboration should initiate it by asking content and ESL teachers to participate (Dove \& Honigsfeld, 2018). In this study, the ESL teacher's commitment to collaboration and agency ultimately worked to sustain it. As such, the ESL teacher may need to lead these conversations because content teachers may not understand ESL students' language and content needs, nor recognize the necessity for collaboration. Once teachers begin to build these collaborative partnerships, they could start small, perhaps with one lesson or unit, and continue to build on these collective efforts (Dove \& Honigsfeld, 2018). Strengthening these partnerships will require a willingness to engage in conversations where teachers discuss the successes and challenges frankly and with transparency (Baecher, Rorimer, \& Smith, 2012). Second, educational stakeholders, namely, administrators, who have the authority and resources, need to create schedules that allot planning and teaching time for collaborating teachers (DelliCarpini, 2018). This may mean that they consider creative ways (e.g., a shared Google folder and/or online video-conferencing tools) to collaborate (Dove \& Honigsfeld, 2018).

Third, ESL and content teachers need to cross the boundaries of their respective content areas so that both teachers can plan and teach language and content objectives to ESL students. This might require additional PD where language teachers are willing to learn the content so that they can make it accessible to ESL students in the mainstream classroom because, ultimately, the ESL teacher's content knowledge and willingness to assume a content teacher's position ultimately sustained collaboration. Concurrently, content teachers learn about second language acquisition and teaching ESL students in the mainstream classroom. Crossing these content boundaries 
will also require that both teachers share in planning and teaching responsibilities even if an unequal division of labour still exists (Peercy, Ditter, \& DeStefano, 2016).

Future studies might investigate how other ESL teachers engage in their own professional self-development opportunities and explore how both content and ESL teachers collectively pursue their own professional self-development to plan for and teach ESL students. This work is crucial across multiple content areas (e.g., language arts, science, and mathematics), especially given the call for ESL and content teachers' collaboration in the United States (Dove \& Honigsfeld, 2018).

Last, this study's findings contribute to the field of language teacher education by providing an example of how an ESL teacher engages in her own professional self-development as she works with a mainstream content teacher in collaborative activity. Critical reflection about definitions of collaboration and how these are enacted in practice create opportunities for continued professional self-development and learning. This examination is crucial to enable ESL teachers to see new possibilities, engage in dialogue about our own learning, and refine our pedagogical practices amid a rapidly changing educational landscape. Such examinations have to continue to explore how ESL teachers engage in the collaborative teaching activity with content teachers and enact their own agency if we are to promote a shared responsibility for ESL instruction, strengthen collegiality, and work toward ESL students' equitable learning outcomes.

\section{Acknowledgements}

I wish to thank the collaborating teacher who shared his classroom with me and voluntarily engaged in collaboration to plan and teach ESL students in the mainstream social studies classroom. I am also grateful to my professor and mentor, Dr. Bedrettin Yazan, for his feedback on earlier versions of this manuscript and for his continuous guidance and support throughout this process. In addition, I wish to thank this special issue's guest editor, Dr. Li-Shih Huang, the anonymous reviewers, and the team at TESL Canada Journal for their constructive comments and suggestions, which strengthened this manuscript's quality.

\section{The Author}

Amanda Giles is a doctoral candidate in the Department of Curriculum and Instruction at the University of Alabama. Her research interests include collaboration between ESL and mainstream content area teachers, literacy, language policy, and effective assessment practices for ESL students. She currently is an ESL teacher at a middle school in the southeastern United States where she currently works to promote equitable educational outcomes for ESL students. Her dissertation research examines how ESL and content teachers' collaboration influences content teachers' learning to plan for and teach ESL students and explores how this collaboration influences ESL students' participation in the mainstream classroom. 


\section{References}

Ahearn, L. M. (2001). Language and agency. Annual Review of Anthropology, 30(1), 109-137. https://doi.org/10.1146/annurev.anthro.30.1.109

Ahmed Hersi, A., Horan, D. A., \& Lewis, M. A. (2016). Redefining "community" through collaboration and co-teaching: A case study of an ESOL specialist, a literacy specialist, and a fifth-grade teacher. Teachers and Teaching: Theory and Practice, 22(8), 927-946. https://doi.org/ 10.1080/13540602.2016.1200543

Arkoudis, S. (2003). Teaching English as a second language in science classes: Incommensurate epistemologies?. Language and Education, 17, 161-173. https://doi.org/10.1080/09500780308666846

Baecher, L., Rorimer, S., \& Smith, L. (2012). Video-mediated teacher collaborative inquiry: Focus on English language learners. The High School Journal, 95(3), 49-61. https://doi.org/10.1353/ hsj.2012.0007

Bair, M. A. (2014). Restricted professionalism of teachers: Implications for collaboration. In S. Conley, \& B. Cooper (Eds.), Moving from teacher isolation to collaboration: Enhancing professionalism and school quality (pp. 27-34). Lanham, MD: Roman \& Littlefield Education.

Biesta, G., \& Tedder, M. (2007). Agency and learning in the life course: Towards an ecological perspective. Studies in the Education of Adults, 39, 132-149. https://doi.org/10.1080/02660830 .2007.11661545

Biesta, G., Priestley, M., \& Robinson, S. (2015). The role of beliefs in teacher agency. Teachers and Teaching: Theory and Practice, 21(6), 624-640. https://doi.org/10.1080/13540602.2015.1044325

Buchanan, R. (2015). Teacher identity and agency in an era of accountability. Teachers and Teaching: Theory and Practice, 21(6), 700-719. https://doi.org/10.1080/13540602.2015.1044329

Creese, A. (2002). The discursive construction of power in teacher partnerships: Language and subject specialists in mainstream schools. TESOL Quarterly, 36(4), 597-616. https://doi. org $/ 10.2307 / 3588242$

Creswell, J. W., \& Miller, D. L. (2000). Determining validity in qualitative inquiry. Theory into Practice, 39(3), 124-130. https://doi.org/10.1207/s15430421tip3903_2

Darling-Hammond, L., Hyler, M. E., Gardner, M., \& Espinoza, D. (2017). Effective teacher professional development. Palo Alto, CA: Learning Policy Institute.

DelliCarpini, M. (2018). Administrative issues in collaborative teaching. In J. Liontas, M. DelliCarpini, G. Park, \& S. Salas (Eds.), TESOL encyclopedia of English language teaching (pp. 1-9). Hoboken, NJ: Wiley.

Dove, M., \& Honigsfeld, A. (2018). Co-teaching for English learners: A guide to collaborative planning, assessment, and reflection. Thousand Oaks, CA: Corwin.

Duff, P. A. (2012). Identity, agency, and second language acquisition. In S. M. Gass and A. Mackey (Eds.), The Routledge handbook of second language acquisition (pp. 410-426). London, UK: Routledge.

Engeström, Y. (2001). Expansive learning at work: Toward an activity theoretical reconceptualization. Journal of Education and Work, 14, 133-156. https://doi.org/10.1080/13639080123238

Freeman, D., \& Johnson, K. E. (1998). Reconceptualizing the knowledge-base of language teacher education. TESOL Quarterly, 32(3), 397-417. https://doi.org/10.2307/3588114

Giles, A. \& Yazan, B. (Forthcoming, 2019). ESL and content area teachers' collaboration. Indonesian Journal of English Language Teaching.

Jenlink, P. M. (2013). Cultural-historical activity theory. In B. J. Irby, G. Brown., R. Lara-Alecio, \& S. Jackson (Eds.), The handbook of educational theories (pp. 219-236). Charlotte, NC: Information Age Publishing, Inc.

Johnson, K. E. (2006). The sociocultural turn and its challenges for second language teacher education. TESOL Quarterly, 40(1), 235-257. https://doi.org/10.2307/40264518

Johnson, K. E. (2009). Second language teacher education: A sociocultural perspective. New York, NY: Routledge. 
Johnson, K. E., \& Freeman, D. (2001). Teacher learning in second language teacher education: A socially-situated perspective. Revista Brasileira de Linguística Aplicada, 1(1), 53-69. https://doi. org/10.1590/s1984-63982001000100004

Johnson, K. E. \& Golombek, P. R. (2016). Mindful L2 teacher education: A sociocultural perspective on cultivating teachers' professional development. New York, NY: Routledge.

Kayi-Aydar, H. (2015). Teacher agency, positioning, and English language learners: Voices of pre-service classroom teachers. Teaching and Teacher Education, 45, 94-103.

Kumaravadivelu, B, (2003). Beyond methods: Macrostrategies for language teaching. New Haven, CT: Yale University Press.

Lave, J., \& Wenger, E. (1991). Situated learning: Legitimate peripheral participation. Cambridge, UK: Cambridge University Press.

Loughran, J. J. (2004). Learning through self-study: The influence of purpose, participants and context. In J. J. Loughran, M. L. Hamilton, V. K. LaBoskey, \& T. Russell (Eds.), The international handbook of self-study of teaching and teacher education practices (pp. 151-192). Dordrecht, The Netherlands: Kluwer.

Martin-Beltrán, M., \& Peercy, M. M. (2014). Collaboration to teach English language learners: Opportunities for shared teacher learning. Teachers and Teaching: Theory and Practice, 20, 721-737. https://doi.org/10.1080/13540602.2014.885704

Merriam, S. B., \& Tisdell, E. J. (2016). Designing your study and selecting a sample. Qualitative research: A guide to design and implementation. San Francisco: John Wiley \& Sons, Inc.

Miles, M. B., Huberman, A. M., \& Saldaña, J. (2014). Qualitative data analysis: A methods sourcebook. Thousand Oaks, CA: Sage.

Peercy, M. M., Ditter, M., \& DeStefano, M. (2016). "We need more consistency": Negotiating the division of labour in ESOL-mainstream teacher collaboration. TESOL Journal, 8(1), 215-239. https://doi.org/10.1002/tesj.269

Peercy, M. M., Martin-Beltrán, M., Yazan, B., \& DeStefano, M. (2017). “Jump in any time": How teacher struggle with curricular reform generates opportunities for teacher learning. Action in Teacher Education, 39(2), 203-217. https://doi.org/10.1080/01626620.2016.1248302

Priestley, M., Edwards, R., Priestley, A., \& Miller, K. (2012). Teacher agency in curriculum making: Agents of change and spaces for manoeuvre. Curriculum Inquiry, 42(2), 191-214. https:// doi.org/10.1111/j.1467-873x.2012.00588.x

Saldaña, J. (2013). The coding manual for qualitative researchers. Thousand Oaks, CA: Sage.

Samaras, A. P. (2011). Self-study teacher research: Improving your practice through collaborative inquiry. Thousand Oaks, CA: Sage.

Smith, K. (2017). Teachers as self-directed learners: Active positioning through professional learning. Singapore: Springer.

Vygotsky, L. (1978). Mind in society: The development of higher psychological processes. Cambridge, MA: Harvard University Press.

Wang, Y., Many, J. E., \& Krumenaker, L. (2008). Understanding the experiences and needs of mainstream teachers of ESL students: Reflections from a secondary social studies teacher. TESL Canada Journal, 25(2), 66-84. https://doi.org/10.18806/tesl.v26i1.130 